\title{
The Child in European Human Rights Law
}

\author{
Sarah Trotter*
}

This article examines the category of 'the child' in European human rights law, based on an analysis of the child-related jurisprudence of the European Court of Human Rights. I argue that a full account of legal selfhood is constructed through the notion of 'the child' in this jurisprudence. The two notions - of 'the child' and 'the self' - are, from the outset, mutually dependent. Thus the article shows how the conceptualisation of 'the child' in human rights law is underpinned by an account of the self as originating in another and how childhood is cast as enabling selfunderstanding by making possible the formation of a narrative about the self. The vision of 'the self that emerges here is one of 'the narrative self, and I assess the implications of this both for the idea of childhood in which this narrative originates and for the vision of the human condition that is expressed in European human rights law more broadly.

\section{INTRODUCTION}

In European human rights law, the category of 'the child' is put to considerable work. 'The child' is at once constructed as an object of desire (the expected or hoped-for child), ${ }^{1}$ as a symbol of commitment and constancy in a relationship between two individuals, ${ }^{2}$ and as a distinct individual whose 'best interests' often reign as paramount. ' 'Childhood' itself, as a space and time occupied by 'the child', emerges as a structure through which vital knowledge is transmitted from 'adults' to 'the young, and as a time for 'the fundamental programming of personality'. ${ }^{5}$ It is in the category of 'the child' that we see, in this way, the articulation and delineation of a vision of the development of 'the individual' more generally - 'the individual' who is then posited as the basic foundational principle of European human rights law, and the protection of whose freedom and dignity forms the central task of human rights law's mission. ${ }^{6}$

\footnotetext{
* Law Department, London School of Economics and Political Science. I am very grateful to Damian Chalmers, Kai Möller, and the anonymous reviewers for their valuable comments and suggestions.

1 eg Paradiso and Campanelliv Italy ECtHR 24 Jan 2017, para.215.

2 eg Kroon and Others $v$ The Netherlands (1995) 19 EHRR 263, para.30; Al-Nashif v Bulgaria (2003) EHRR 37, para.112; Joseph Grant v UK ECtHR 8 Jan 2009, para.30.

3 eg Neulinger and Shuruk v Switzerland (2012) 54 EHRR 31, para.135.

${ }_{4}$ Campbell and Cosans v UK (1982) 4 EHRR 293, para.33.

5 Maumousseau and Washington v France (2010) 51 EHRR 35, Dissenting Opinion of Judge Zupančič, joined by Judge Gyulumyan, para.O-I4.

6 See eg Goodwin v UK (2002) 35 EHRR 18, para.90: 'the very essence of the Convention is respect for human dignity and human freedom'.
} 
Thus within the structure of European human rights law, the category of 'the child' is of fundamental significance; and the complexity of the condition and meaning of being a child within the vision of human rights law accordingly calls for further analysis. That is the contribution of this article; and in the pages that follow, I set out an account of the category of 'the child' in European human rights law, based on an analysis of all the child-related jurisprudence of the European Court of Human Rights (ECtHR) to date. ${ }^{7}$ The main argument that I put forward here is that a full account of legal selfhood is constructed and set out through the notion of 'the child' in European human rights law. Within the conceptualisation of 'the child', thus, there is not only an account crafted out of 'the child' as firmly situated in the context of its parents, and of the role of the 'other' in constructing 'the child', but there is also an account of the self as originating in another (Section A). Childhood is deemed vital in this context, insofar as two processes which are considered fundamental to the formation of the self - individuation and habituation - originate in childhood (Section B). Individuation is about the delineation of the specific child, and the articulation of her interests (as distinct from those of her parents), and habituation is about the engraining of actions and elements of being as habits, such that they become unconscious features of an individual's character. Childhood, in this way, is accorded such an integral role in human rights law's account of the formation of the self that it is cast as supplying the framework through which life is subsequently structured and interpreted (Section C). The idea underlying the case law here is that an account of childhood enables self-understanding, because it makes possible the formation of a narrative about the self. The vision of 'the self' that emerges from the depths of the category of 'the child' in European human rights law is, accordingly, a vision of 'the narrative self.

\section{A. 'THE CHILD'}

That 'the child' is constructed as a category in European human rights law comes to the fore most clearly in cases in which no specific child is identified and rather a very general idea of 'the child' is imagined. Such is the case, for example, in instances concerning application procedures for authorisation to adopt a child, in which the lack of identification of a 'specific child' does not rule out the fact of the centrality to be accorded in such cases to the 'best interests' of 'children' in general. ${ }^{8}$ The generality and indeterminacy of this notion leaves a lot of scope for imagining what these 'best interests' are; and that imagination, in turn, presupposes some conception of 'children' as a class and the category of 'the child' in the first place. This category then comes to carry a

\footnotetext{
${ }^{7}$ The paper is based on an examination of all the ECtHR cases up to 1 June 2017 which feature the word 'child' (or any other associated words, such as 'childhood', 'juvenile', 'minor', 'baby', 'parent', or 'pupil').

${ }^{8}$ Fretté v France (2004) 38 EHRR 21, para.42; E.B. v France (2008) 47 EHRR 21, para.76.
} 
normative and normalising force; and it is in this context that notions such as of the 'normal development' of the family life of the child ${ }^{9}$ and of what a 'normal childhood' consists in ${ }^{10}$ make their way into the jurisprudence of the ECtHR.

Once the category of 'the child' is accorded a life of its own in this way, tensions occasionally arise between the weight of this category - as a socio-legal construction - and the concrete interests of a specific child. An example is $X, Y$, and $Z v U K$ (1997), in which the Applicants complained of the lack of legal recognition of the father-child relationship between $\mathrm{X}$ (a female-to-male transsexual) and $\mathrm{Z}$ (the child, who had been conceived by donor insemination and carried by Y, X's partner). The Applicants alleged that this had breached their right to respect for their family life under Article 8 ECHR; and in particular, they argued that it might undermine Z's 'sense of security within the family'. ${ }^{11}$ The Court, however, considered that the concerns of the Applicants about the particular position of $\mathrm{Z}$ could be circumvented by, for example, making a will (to mitigate the effect of the intestacy laws, which would not grant $\mathrm{Z}$ an automatic right to inherit from X) and concealing the reason as to why X's name was absent from Z's birth certificate (which was that $\mathrm{X}$ had been born female). Instead, the Court was more occupied with the idea that granting the legal recognition demanded here might not necessarily be to the advantage of children conceived by artificial insemination in this way 'in general'. ${ }^{12}$ In the light of this uncertainty, the Court preferred to protect the stability of its category of 'the child' - a category which, under Article 8, does not oblige States 'formally to recognise as the father of a child a person who is not the biological father ${ }^{13}$ - over the specific interests of $\mathrm{Z}$ and her family in having their relationships legally recognised.

The question that arises, against the backdrop of the normativity of this category and the importance that is accorded in law to its stability, is of the form that is taken by 'the child' itself; and in what follows, I examine both how 'the child' is imagined and how, in this light, 'the child' is conceptualised as emerging and coming into being. I suggest that such is the weight that is accorded to the 'other' in the process of constructing 'the child' - 'the child' not least being always imagined by another before actually coming into being itself - that what emerges here is a notion of the self, more generally, as originating in another.

\footnotetext{
${ }^{9}$ eg Marckx v Belgium (1979-80) 2 EHRR 330, para.36; Johnston and Others v Ireland (1987) 9 EHRR 203, para.74; M.P. and Others v Bulgaria ECtHR 15 Nov 2011, para.132.

10 eg Orzet v Poland ECtHR 25 March 2003, para.54.

${ }^{11} X, Y$ and $Z v$ UK (1997) 24 EHRR 143, para.45.

$12 \mathrm{ibid}$, para. 47.

13 ibid, para.52.
} 


\section{Imagining 'the child'}

The construction of the idea of 'the child' in European human rights law is bound up in the notion of 'the parent', and, in particular, in the right that is recognised in the ECHR jurisprudence to respect for the decision whether or not to become a parent. This was articulated most fully in Evans v UK (2007), which concerned the competing interests of Ms Evans and her former partner, J., in relation to six embryos that they had had frozen together, prior to surgery on Ms Evans to remove her ovaries. At the time of the treatment, Ms Evans and J. each signed a form which stated that under the Human Fertilisation and Embryology Act, it would be possible for either of them to withdraw their consent to the use of the embryos at any time prior to implantation (the joint consent' rules). Not long after, they broke up, and J. told the clinic that he wanted the embryos to be destroyed. Ms Evans objected, and ultimately argued before the Grand Chamber of the ECtHR that the domestic provisions enabling J. to withdraw his consent in this way violated her Article 8 ECHR rights. In particular, she complained that the effect of the joint consent rules was that she was denied her only chance of having a genetically-related child. The conflict was between her decision to become a parent, and J's decision not to.

Ultimately, J's right to respect for his decision not to become a genetic parent outweighed Ms Evans's right, and no violation of Article 8 was found. Whilst there is, to be sure, a broader question to be asked as to why J's right prevailed in this way, ${ }^{14}$ what is particularly notable for our purposes here - from the perspective of how 'the child' is envisaged - is that the Grand Chamber considered that the right to respect for private life incorporates the right to respect for both the decisions to become and not to become a parent. ${ }^{15}$ The Court, moreover, recognised Ms Evans's desire to fulfil herself as a genetic parent, and tried to find a way around the fact that, with its decision, she would not have the chance to realise herself in this way. It tried to veil her loss by suggesting alternative routes to parenthood: she was thus not prevented 'from becoming a mother in a social, legal, or even physical sense';16 'only' genetic parenthood was in issue. In other words, Ms Evans, according to human rights law, could still realise her potential as a mother, just in different senses.

\footnotetext{
${ }^{14}$ See also Parrillo v Italy (2016) 62 EHRR 8, para.196, in which, overall, Ms Parrillo's deceased partner similarly acquired something of a final say in relation to the fate of their frozen IVF embryos (which Ms Parrillo wanted to donate to scientific research).

15 Evans v UK (2008) 46 EHRR 34, para.71.

16 ibid, para. 72 .
} 
This notion that the Court set out, of individual fulfilment as parent, and cast more recently in terms of 'personal development through the role of parents, ${ }^{17}$ runs throughout the cases in which the right to respect for the decision over whether or not to become a parent is perceived by the Court as being at stake. ${ }^{18}$ It relies on a vision of the role played by the child in the wellbeing of the potential parent; and 'the child' is constructed, in the first instance, as being an object of desire, imagined by the parent(s) and invested with hope and expectation. ${ }^{19}$ This comes to light most clearly where intended family life is at issue, which is sometimes - exceptionally ${ }^{20}$ - deemed sufficiently strong to fall within the net of 'family life' cast by Article 8 ECHR, even though the Court has otherwise tended to maintain that this provision 'presupposes the existence of a family.' ${ }^{21}$ Thus in Pini and Others $v$ Romania (2004), for example, in which two Italian couples, who had gone through proceedings to adopt two Romanian children, complained that there had been a failure to execute the decisions of the domestic courts concerning the adoptions, in violation of their right to respect for their family life, the 'family life' limb of Article 8 was indeed deemed applicable. The Court considered that although 'family life' had not been 'fully established', since 'the applicants have not lived with their respective adopted daughters or had sufficiently close de facto ties with them either before or after the adoption orders were made', this was not the fault of the Applicants, who had merely followed the Romanian adoption procedure. ${ }^{22}$ The Applicants had 'always viewed themselves as the girls' parents and behaved as such towards them through the only means open to them, namely by sending them letters written in Romanian' ${ }^{\prime 23}$ and this relationship, it considered, 'arising from a lawful and genuine adoption', sufficed to attract the respect accorded to family life under Article $8 .^{24}$

Accordingly, it was the fact that the Applicants viewed themselves as the parents of the children that was the focus of the Court in establishing that the relationship fell within the ambit of Article 8. The Court, in this way, concentrated on how the children were imagined - on the meaning that was projected onto them by their adoptive parents, and the way in which they were thereby situated within a particular set of familial relationships. This process of self-imagination

\footnotetext{
17 Paradiso and Campanelli v Italy ECtHR 24 Jan 2017, para.163.

18 eg Dickson v UK (2008) 46 EHRR 41, para.66; S.H. and Others v Austria ECtHR 3 Nov 2011, para.82.

19 eg Costa and Pavan v Italy ECtHR 28 Aug 2012, on the protection under Article 8 of the desire of the Applicants (who were healthy carriers of cystic fibrosis) to conceive a healthy child, and to use preimplantation genetic diagnosis to that end (para.57).

${ }^{20}$ Krisztián Barnabás Tóth v Hungary ECtHR 12 Feb 2013, para.27.

21 See Pini and Others $v$ Romania (2005) 40 EHRR 13, para.143. The origins of this notion lie in Marckx v Belgium (1979-80) 2 EHRR 330, para.31.

22 Pini and Others $v$ Romania (2005) 40 EHRR 13, para.146.

23 ibid, para.147.

24 ibid, para.148.
} 
and projection is presented in European human rights law as being the means through which the individual child is envisaged in the first instance. The child is cast as being the object of an individual's imagination of his or her self as 'parent', meaning that the origins of the idea of the individual child are located in the mind of another.

\section{The emergence of 'the child'}

It is against the backdrop of this imagination that the particular 'child' comes into being: 'the child' who is imagined and called into being by another, and the choice of whose forename - this name being the means for all subsequent calling - forms a matter of the private life rights of its parents. ${ }^{25}$ This child is located firmly in the relationship that exists (or once existed) between the parents; ${ }^{26}$ and in fact in deportation cases, and indeed more generally, the Court takes the existence of a child born to a couple to be demonstrative of 'their commitment to each other' for purposes of establishing whether their relationship amounts to 'family life' under Article $8 .{ }^{27}$ Thus the positions of the child and of the parent(s) are set up to be intertwined from the outset.

This vision, of the child and the parent as having closely connected interests, underpins the conception of parental rights that has been developed in the ECHR jurisprudence; and that notion, in turn, supports a construction of the child as being an extension of the parent. At one level, therefore, it is stipulated that the religious and philosophical convictions of the parents are to be respected, as a matter of parental right, in the course of the fulfilment of the right of the child to education. ${ }^{28}$ But if we dig a little deeper, we see that in that same line of cases on education, such is the weight that is accorded to the religious and philosophical convictions of the parents and to the possible effects of a school curriculum or exemption procedure on these parents ${ }^{29}-$ that what effectively emerges here is a construction of the exercise of the rights of the parents through the child. This perspective, of the child as an extension of the parent, harks back to a

\footnotetext{
25 eg Guillot v France ECtHR 24 Oct 1996, para.22. Though see also Johansson v Finland (2008) 47 EHRR 14, para.36, in which the Court accepted the Government's argument that the Names Act (by reference to which the authorities had refused to register the forename 'Axl' that the Applicants had chosen for their son) pursued an aim that was in the public interest: ' $\mathrm{t}$ ] he protection of the child from an unsuitable name (such as ridiculous or whimsical names)' and the interest in protecting the language (by preserving the 'national name practice').

${ }^{26}$ Thus a child born of a cohabiting or married couple will be "part of that "family" unit from the moment, and by the very fact, of its birth': L. $v$ The Netherlands ECtHR 1 June 2004, para.35. This goes back to Berrehab $v$ The Netherlands (1989) 11 EHRR 322, para.21 (a child born to a married couple 'is ipso jure part of that relationship'). 27 eg Al-Nashifv Bulgaria (2003) 36 EHRR 37, para.112. This is more generally used as a criterion for establishing whether a relationship between a couple amounts to 'family life' for Article 8 purposes: Emonet and Others v Switzerland (2009) 49 EHRR 11, para.36.

28 eg Kjeldsen, Busk. Madsen and Pedersen v Denmark (1979-80) 1 EHRR 711, para.50.

29 eg Folgero and Others v Norway (2008) 46 EHRR 47; Zengin v Turkey (2008) 46 EHRR 44; Mansur Yalçn and Others $v$ Turkey ECtHR 16 Sept 2014.
} 
much older notion of parental authority and control; and in European human rights law, the exercise of this parental authority is protected under Article 8 as a matter of parental right. ${ }^{30}$

The close identification of the child and the parent in this way, and the conceptualisation of the emerging child as an extension of the parent, culminates in the inclusion of matters pertaining very closely to the child within the 'private life' of a parent. An example is Znamenskaya $v$ Russia (2005), in which Ms Znamenskaya complained that the refusal of the domestic courts to establish the paternity of her stillborn baby boy and to change his name on the register accordingly (from the name of her former husband to that of her late partner, Mr G.) had violated her own Article 8 rights. She had been living with Mr G. since 1994, and they had expected the child together. But there had followed a series of losses for Ms Znamenskaya: Mr G. was placed in detention in June 1997, the baby was lost in August 1997, and Mr G. died in custody in October 1997.

The ECtHR considered that the establishment of the paternity of the stillborn baby 'undoubtedly affected' Ms Znamenskaya's private life. ${ }^{31}$ This was because of the 'strong bond' that must have developed between Ms Znamenskaya and 'the embryo whom she had almost brought to full term' - a bond that was reflected in the fact that 'she expressed the desire to give him a name and bury him' ${ }^{32}$ Moreover, there were no conflicting interests at stake: nobody had contested that there had been a relationship between Mr Znamenskaya and Mr G., there had been no dispute of his paternity of the stillborn baby, and establishing paternity would not, in this instance, impose any maintenance obligations on anyone. The domestic courts had not invoked any 'legitimate or convincing reasons for maintaining the status quo' here, and the ECtHR considered that ultimately, it was not compatible with Article 8 for the State to allow the legal presumption that Ms Znamenskaya's former husband was the father to 'prevail over biological and social reality, without regard to both established facts and the wishes of those concerned and without actually benefiting anyone'. ${ }^{33}$ It consequently found that Ms Znamenskaya's Article 8 right to respect for her private life had been violated.

This presentation, of the status of the purportedly biological father as a matter of Ms Znamenskaya's private life, is, on the one hand, understandable. Accurate legal recognition of the

\footnotetext{
$30 \mathrm{eg}$, Nielsen v Denmark (1989) 11 EHRR 175, para.61. The Court here considered that the admission of Mr Nielsen to a psychiatric ward as a child and at the request of his mother did not constitute a deprivation of his liberty, as Mr Nielsen had argued; rather, it was 'a responsible exercise by his mother of her custodial rights in the interests of the child' (para.73). See also Diamante and Pelliccioni v San Marino ECtHR 27 Sept 2011, para.170.

31 Znamenskaya v Russia (2007) 44 EHRR 15, para.27

32 ibid, para. 27.

33 ibid, para.31.
} 
paternity of her stillborn child would, evidently, have been of very deep concern to Ms Znamenskaya, who, having lost both her baby and her partner, sought formal recognition of the family unit that could have been - a sort of recognition that has elsewhere been cast as a question of 'social image'. ${ }^{34}$ It is notable, in this regard, that despite its stated intention, the Court struggled to consider this case solely in terms of the 'private life' limb of Article 8, and rather invoked the notion of 'family life' time and again too. ${ }^{35}$ At the same time, the submergence of the position of Mr G., the purportedly biological father, within the 'private life' of the mother drew subtle criticism in the Joint Dissenting Opinion of Judges Rozakis, Botoucharova, and Hajiyev. They raised the question of whether the State's refusal to recognise the child's biological father as an element of Ms Znamenskaya's right to respect for her private life might not have been 'justified by the fact that the most interested party - the father of the child - was not alive at the time of the request and, hence, was unable to protect his rights in respect of his name and his family life. ${ }^{36}$ Such a consideration has on other occasions been a significant factor in swinging the balance of the outcome of the Court, ${ }^{37}$ but here it played no role in the reasoning of the majority. Rather, the focus was on establishing recognition of the family unit that did not come to pass, and on positioning Ms Znamenskaya within this. It was to the end of locating the origins of Ms Znamenskaya's current predicament that the Court constructed the origins of the child - in terms of his paternity - as being a matter of the private life of his mother.

\section{The origins of the self}

Thus 'the child' comes into European human rights law in the context of 'the parent', being firstly the object of an individual's imagination of his or her self as 'parent', and being secondly located within a parental relationship and constructed as an extension of the parent(s). It is against this backdrop of the weight that is accorded to 'the parent' in the process of constructing 'the child'

\footnotetext{
${ }^{34}$ See Kalacheva $v$ Russia ECtHR 7 May 2009, a case in which Ms Kalacheva complained about the failure of the domestic courts to establish the paternity of her daughter's father, despite DNA tests which indicated with 99.99 per cent accuracy who he was. In considering that the case fell within the ambit of Ms Kalacheva's Article 8 private life right, the Court noted that she bore the responsibility for her child, and that recognising the biological father would not only be important for financial and emotional reasons, but 'may also be important from the point of view of the applicant's social image...' (para.29).

35 Thus it noted the positive obligations that are inherent in effective respect for family life under Article 8 (Znamenskaya v Russia (2007) 44 EHRR 15, para.28) and considered also that the approach taken by the State here had not complied with 'the obligation to secure effective 'respect' for private and family life' (ibid, para.31). 36 ibid, Joint Dissenting Opinion of Judges Rozakis, Botoucharova and Hajiyev, para.O-I6.

37 eg Parrillo v Italy (2016) 62 EHRR 8. The case concerned the fate of the frozen IVF embryos of Ms Parrillo and her late partner. She wanted to donate them to scientific research, but the Grand Chamber, in reasoning that the Government had not overstepped its margin of appreciation in prohibiting this, noted that it was significant that it had no evidence that Ms Parrillo's deceased partner, 'who had the same interest in the embryos in question as the applicant at the time of fertilisation, would have made the same choice' as she was seeking to make (para.196).
} 
that the notion of the right to knowledge of origins has to be understood. This is precisely about the origins of the child in another, and it sets out the implications - from the perspective of the child - of the vision in which the child is constructed as an extension of the parent(s).

The right to knowledge of origins has itself been derived by the Court from its interpretation of the Article 8 notion of 'private life, ${ }^{38}$ and it has been invoked most explicitly in a line of case law concerning 'access to information about one's origins and the identity of one's natural parents'. ${ }^{39}$ These cases involve such instances as when an adopted child seeks to trace her anonymous biological mother - a situation which has arisen in particular in the context of the legal possibility, which exists in some countries (and most notoriously, France ${ }^{40}$ ), of anonymous birth. This enables women to give birth anonymously, and not to be recorded on the child's birth certificate. In such cases, the Court conceptualises the substance of the child's claim to knowledge of her origins in terms of "personal development'. ${ }^{41}$ The idea is not necessarily that the child's personal development will be blocked in the absence of knowledge of her parentage, but it is certainly that this will be hindered. In Godelli v Italy (2012), for example, in which the sixty-nine year old Applicant, who had been born anonymously, was seeking information about her biological mother, the Court noted that 'whilst it was true' that she had 'been able to develop her personality, even in the absence of certainty as to the identity of her birth mother, it must be acknowledged that an individual's interest in discovering his or her parentage does not disappear with age, quite the reverse'. ${ }^{42}$ The fact that she had 'shown a genuine interest in ascertaining her mother's identity' implied 'mental and psychological suffering, even if this had not been medically attested' ${ }^{43}$

The identity of one's biological parents is, in this way, presented as being a part of one's individual identity, and, therefore, as being 'of relevance to personal development'. ${ }^{44}$ Where a child is lacking this information, a notion of 'truth' is introduced, and the case is cast as concerning the individual interest in 'obtaining information necessary to discover the truth concerning important aspects of one's personal identity'. ${ }^{45}$ The theory underpinning European human rights law here is that knowledge of one's biological origins plays an important role in one's personal identity, such

\footnotetext{
38 Odière v France (2004) 38 EHRR 43, para.44.

39 ibid, para.43.

40 Anonymous birth is most established in France, where it has existed since a law of 28 June 1793 and is now set out in Article 326 of the Civil Code. The Italian equivalent was at issue in Godelli v Italy ECtHR 25 Sept 2012.

41 Odièvre v France (2004) 38 EHRR 43, paras.29, 44.

42 Godelli v Italy ECtHR 25 Sept 2012, para.56.

43 ibid, para.56. See also Jäggi v Switzerland (2008) 47 EHRR 30, para.40.

44 Odière v France (2004) 38 EHRR 43, para.29

45 ibid, para.29
} 
that the discovery of this information, in its prior absence, stabilises personal identity, and enables individual development.

The same idea emerges in cases in which children are seeking to resolve the question of their own paternity, which are similarly presented as cases concerning questions of 'biological truth', in which the 'personal identity' of the Applicants is entirely at stake. ${ }^{46}$ An example is Jäggiv Switzerland (2006), in which Mr Jäggi, the sixty-seven year old Applicant, complained that the refusal of the domestic courts to allow him to have a DNA tests on the remains of A.H., his putative biological father (but who had always denied paternity of Mr Jäggi and had refused to undergo paternity tests), violated his right to respect for his private life.

The Court here restated the importance, to one's private life, of 'the right to an identity, which includes the right to know one's parentage', and considered that consequently, this case called for 'particularly rigorous scrutiny...when weighing up the competing interests'. ${ }^{47}$ These interests consisted in, on the one hand, the right of Mr Jäggi to 'establish his paternity', and, on the other hand, 'the right of third parties to the inviolability of the deceased's body, the right to respect for the dead, and the public interest in preserving legal certainty'. ${ }^{48}$ In particular though, A.H.'s family had not presented 'any religious or philosophical grounds for opposing the taking of a DNA sample', a measure which, the Court considered, was 'relatively unintrusive'. ${ }^{49}$ The only reason that A.H.'s remains had not been moved up until now was that Mr Jäggi had renewed the lease on his tomb up until 2016: '[o]therwise, the peace enjoyed by the deceased and the inviolability of his mortal remains would already have been disturbed at that time', as it would be in 2016. ${ }^{50}$ And so, the Court considered, '[t]he right to rest in peace therefore enjoys only temporary protection'. ${ }^{51}$ By contrast, Mr Jäggi's interest was an 'overriding one', and, the Court concluded, his right to respect for his private life had been violated by the Swiss authorities. ${ }^{52}$ The sense here was that the disruption that a DNA test would impose on the deceased would be minimal by comparison with the lifelong disruption that Mr Jäggi had experienced to his personal identity.

\footnotetext{
46 eg Mikulic v Croatia ECtHR 7 Feb 2002, paras.55, 65-66; Jäggi v Switzerland (2008) 47 EHRR 30, paras.37-39; Jevremović v Serbia ECtHR 17 July 2007, paras.106, 110; Pbinikaridou v Cyprus ECtHR 20 Dec 2007, para.53.

47 Jäggi v Switzerland (2008) 47 EHRR 30, para.37.

48 ibid, para.39.

49 ibid, para.41.

50 ibid, para.41.

51 ibid, para.41.

52 ibid, para. 44.
} 
Personal identity is, in this way, portrayed as being supported by the establishment, in law, of biological origins. As part of this vision, the subjectivity of the child is, from the outset, cast as being bound up in another. The dependency that this generates has been theorised more fully by Butler, who, through the lens of the idea of 'passionate attachments', describes the way in which 'no subject emerges without a passionate attachment to those on whom he or she is fundamentally dependent'. ${ }^{53}$ The child's 'dependency and...formation of attachment', which is the basis of her subordination, is also, therefore, the condition of her persistence as 'child'; '54 'the child' is, on this account, inevitably and permanently embedded in a structure of dependency. This renders problematic the assertion of the ECtHR, made in a case involving a challenge brought by an adult (who had been born anonymously) to the French anonymous birth system, that what was at stake here was not the competing interests of 'an adult and a child', 'but two adults, each endowed with her own free will' (the interests of the anonymous woman and those of the child she delivered under X). ${ }^{55}$ This statement, as will be immediately apparent, seeks to convey a sense of equality that is antithetical to the ECtHR's own hierarchical vision of the issue. For that vision, as we know, is one which squarely locates the origins of personal identity in another, and thereby founds this personal identity upon an original and inescapable inequality. This means that in matters of biological origins, the parties are never equally positioned.

The right to knowledge of origins in European human rights law is not only, therefore, about the origins of the child, as subject, in another. It is also constructed as appealing to a more primitive notion, which is about the origins of personal identity - the origins of the self - in another. The vision underpinning the jurisprudence here is that there is, moreover, some scope for stabilising and resolving the individual quest for personal identity - a stabilisation and resolution which, law here suggests, consists in the realisation of the possibility of locating one's self in another.

\section{B. CHILDHOOD}

The category of 'the child' in European human rights law is, therefore, as much about the origins of the self in law as it is about the origins of 'the child'. The child is conceptualised in the context of - and as an extension of - its parents, and what this implies from the perspective of the child is that the origins of the self are located in another. This construction of the child is not, however, the only one that is adopted in European human rights law. There is also an account to be found

\footnotetext{
${ }^{53}$ J. Butler, The Psychic Life of Power: Theories in Subjection (Stanford: Stanford University Press, 1997), 7.

54 ibid, p8.

55 Odièrre v France (2004) 38 EHRR 43, para.44.
} 
in the case law of the individuation of the child. This consists in the delineation of the individual child, and the articulation of her interests, as distinct from those of her parents and others around her. This process of individuation sits alongside a process of habituation, which is about the engraining of actions and ways of being, such that they become unconscious features of one's character. In the following pages, I suggest that individuation and habituation are conceived of as being critical developmental processes that originate in childhood and are integral to the formation of the self.

\section{Individuation}

The articulation, in European human rights law, of the individual child, as distinct from the general idea of 'the child', and as distinct also from the child's parents and others around her, occurs primarily through the lens of the 'best interests' principle. In the way in which this is conceived of in the jurisprudence of the ECtHR, it stipulates that in all decisions concerning children, the primary, or paramount, consideration is the 'best interests' of the child, ${ }^{56}$ of which a 'personal development perspective' is taken. ${ }^{57}$ In cases involving parent-child relations, the vision of what a child's 'best interests' actually consist in essentially hinges on two things: 'that the child's ties with its family must be maintained, except in cases where the family has proved particularly unfit', and that 'it is in the child's interest to ensure its development in a sound environment, and a parent cannot be entitled under Article 8 to have such measures taken as would harm the child's health and development'. ${ }^{58}$ And so whilst, on the one hand, the 'best interests' principle appears to enable the interests of a specific child, in a specific case, to be delineated, ${ }^{59}$ it has also enabled the articulation of a much more general and normative account of child development.

The first element of this account - the point about family ties - is a reflection of the most basic principle of the Article 8 'family life' jurisprudence, which is that ' $[t]$ he mutual enjoyment by parent and child of each other's company constitutes a fundamental element of family life' ${ }^{60} \mathrm{It}$

\footnotetext{
${ }^{56}$ See esp. Neulinger and Shuruk v Switzerland (2012) 54 EHRR 31, paras.134-135. Notably, in para.134, the Grand Chamber refers to the child's best interests as 'the primary consideration', and then, in para.135, notes the consensus established as to the 'paramount' position of these interests. The distinction between a consideration of the child's best interests as 'primary' and 'paramount' is a significant and much-debated one. See eg Baroness Hale's comment in her leading judgment in the UK Supreme Court case of ZH (Tanzania) v Secretary of State for the Home Department [2011] 2 AC 166, 179, para.25, in the context of an analysis of the Strasbourg jurisprudence: 'despite the looseness with which these terms are sometimes used, 'a primary consideration' is not the same as 'the primary consideration', still less as "the paramount consideration"'.

57 Neulinger and Shuruk v Switzerland (2012) 54 EHRR 31, para.138.

58 ibid, para.136. See also R and H v UK (2012) 54 EHRR 2, para.74; Mamchur v Ukraine ECtHR 16 July 2015, para.100.

${ }^{59} \mathrm{eg}$ the interests of the child as distinct from those of her siblings: Vujica v Croatia ECtHR 8 Oct 2015, paras.99103.

${ }^{60}$ eg $W . v U K(1988) 10$ EHRR 29, para.59.
} 
represents a development of the vision, laid out in the first part of this paper, that 'the child' is located in the context of her parents. Here, the child is articulated as having an independent interest in maintaining (or indeed severing) these ties, and this translates into a series of obligations, on the part of domestic authorities, in relation to the maintenance of the relationship between a child and her parents. These are both positive obligations (for instance, obligations to enable an established family tie with a child to be developed, ${ }^{61}$ to ensure the continuation of family life between parents and children in the event of parental separation, ${ }^{62}$ or 'to rehabilitate the child and parent, where possible', in public care cases ${ }^{63}$ ) and negative obligations ('to refrain from measures which cause family ties to rupture $\left.{ }^{64}\right)$. The sense is that disruption to an established parent-child relationship is to be kept to a necessary minimum, ${ }^{65}$ because even a temporary measure can have a long-lasting effect on a child, as it can indeed also on a parent. ${ }^{66}$ And so in cases in which a child has been taken into care, for instance, although the domestic authorities are granted a margin of appreciation in assessing the need for a care order in the first place (particularly if it is an emergency order ${ }^{67}$ ), any further limitations imposed on the parent-child relationship, such as to contact, will be more strictly scrutinised. ${ }^{68}$ This is because, particularly in cases involving young children, restrictions beyond the care order 'entail the danger that the family relations between the parents and a young child are effectively curtailed ${ }^{69}$ and that the children experience 'alienation' from their parents; ${ }^{70}$ and authorities, accordingly, have to take steps to ensure that the chances of re-establishing a disrupted relationship are not 'definitively compromised'. ${ }^{71}$ Where children have spent time in care, the authorities are obliged to ensure that the children and parents are prepared for their reunion. ${ }^{72}$

If this first element of the account of the child's 'best interests' in European human rights law is focused on the child's own interest in the maintenance of the child-parent relationship, it is in relation to the second element - as to the development of the child in a 'sound environment'

\footnotetext{
61 eg Keegan v Ireland (1994) 18 EHRR 342, para.50.

62 eg Ciliz v The Netherlands ECtHR 11 July 2000, para.62.

63 TP and KM v UK (2002) 34 EHRR 2, para.78. See also Hokkanen v Finland (1995) 19 EHRR 139, para.55.

${ }^{64}$ Cilizv $v$ The Netherlands ECtHR 11 July 2000, para.62.

65 This objective of ultimate reunion (for example, in public care cases) does not, however, entitle a parent 'to have such measures taken as would harm the child's health and development': Johansen v Norway (1997) 23 EHRR 33, para. 78 .

${ }^{66} \mathrm{eg}$ P, C, and S v UK (2002) 35 EHRR 31; Haase v Germany (2005) 40 EHRR 19, paras.101-103; EP v Italy (2001)

31 EHRR 17, para.68. On the effect on the child of separation from biological parents, as compared with the effect of separation from foster parents, see Görgülü v Germany ECtHR 26 Feb 2004, paras.43-46.

${ }^{67} \mathrm{~K}$ and $T$ v Finland (2003) 36 EHRR 18, para.165 et seq.

68 Johansen v Norway (1997) 23 EHRR 33, para.64.

69 ibid. Any 'total severance of contact' will be justified only in exceptional circumstances: Scozzari and Giunta $v$ Italy (2002) 35 EHRR 12, para.170.

70 Kutzner v Germany (2002) 35 EHRR 25, para.79.

71 eg EP v Italy (2001) 31 EHRR 17, para.69.

72 eg Olsson v Sweden (No. 2) (1994) 17 EHRR 134, para.90.
} 
- that the individuation of the child emerges even more clearly. This element is not a first-order principle. It does not mean, for example, that the removal of a child from her parents would be justified on the sole ground that there exists, somewhere else, a potentially 'more beneficial environment' for her. ${ }^{73} \mathrm{~A}$ 'good enough' environment, to paraphrase Winnicott, ${ }^{74}$ is all that matters, although everything hinges, of course, on what 'good enough' means. Rather, what this element of the vision of the child's best interests does ultimately establish is that the emotional interest of the child is generally conceived of as being bound in her own stability, not in the emotional wellbeing of her parents. ${ }^{75}$ And so if, for example, a child, over time, becomes settled in a 'new' environment, or with 'new' living arrangements, however temporary or contrary to a court order these were intended to be, it may be in her best interests - as distinct from those of her parent(s) - to leave her there and not to enforce any original order to the contrary. ${ }^{76}$ Thus in child custody cases, 'the passage of time...can, in the end, determine what is in the best interests of the child'; ${ }^{77}$ and that in itself underpins a whole host of obligations that domestic authorities have in relation to the enforcement of orders (pertaining to contact or custody with the other parent, or ordering the child to be removed or returned to live with the other parent, for example ${ }^{78}$ ) and in relation to decision-making processes and the determination of issues before courts. ${ }^{79}$

Through the lens of the 'best interests' principle, the child is, in this way, presented as being an individual actor, with distinctive interests; and the instigation of the gradual individuation of the child thus emerges as being one of the integral processes contained within human rights law's vision of childhood. At the same time, however, and underpinning this notion of individuation, there lies a normative account of the nature of the child's interests - an account in which a 'secure and emotionally stable' environment is constructed as being a defining interest. ${ }^{80}$

${ }^{73} \mathrm{~K}$ and $\mathrm{T} v$ Finland (2003) 36 EHRR 18, para.173. See also eg Olsson v Sweden (No. 1) (1989) 11 EHRR 259, para.72; Saviny $v$ Ukraine (2010) 51 EHRR 33. Notably, the question of justification here is as to the necessity of the interference with the right of the parents, under Article 8, to enjoy family life with their child.

${ }^{74}$ D. W. Winnicott, 'Transitional Objects and Transitional Phenomena' (1953) The International Journal of PsychoAnalysis 34(2), 89-97, 94.

75 Cf. the Dissenting Opinion of Judge Zupančič, joined by Judges Panţîru and Türmen in Nuutinen v Finland (2002) 34 EHRR 15, para.O-I9: 'In custody litigation the best interests of the child are the foremost, although not the only, criterion of justice. Our own case-law indicates that the best emotional interests of the child are inextricably bound up with the emotional interests of both parents - or even those of the grandparents and other relatives.'

76 eg Wv UK (1988) 10 EHRR 29, para.62; Gnahoré v France (2002) 34 EHRR 38, para.60.

77 Nuutinen v Finland (2002) 34 EHRR 15, Dissenting Opinion of Judge Zupančič, joined by Judges Panţîru and Türmen, para.O-I30.

78 The ECtHR has become increasingly strict about the enforcement of orders and about the use of sanctions to secure such enforcement. See eg 48206/99, Maire v Portugal (2006) 43 EHRR 13, para.76.

79 eg Glaser v UK (2001) 33 EHRR 1, para.66.

80 Johansen $v$ Norway (1997) 23 EHRR 33, para.80. See also eg B v UK (2006) 42 EHRR 11, para.36; Kearns v France (2010) 50 EHRR 33, para.80. 
Any uncertainty or disruption that is experienced by the child in relation to her family relationships and her familial environment is deemed damaging and destabilising for the child's development. ${ }^{81}$ Indeed, such is the weight that is accorded to the child's stability in European human rights law that in another line of case law, it has even served as a justification for blocking off potential biological fathers. There are therefore examples of paternity challenges in which the Court has focused on securing and preserving the stability of the child's home environment - the 'existing' social family unit - in the face of the 'threat' of disruption posed by the man claiming to be the legal father of the child in question. ${ }^{82}$ This runs counter to the weight that is otherwise attached, as we earlier saw, to 'biological truth' and knowledge of origins in the constitution of the self; and the resistance to the potential biological fathers here entails their representation as replaceable men (the social father now being the one who is performing the role of 'fathering', and, therefore, being experienced by the other as his replacement). ${ }^{83}$ It also, however, entails a particular use of the 'stability' of the child, because the resistance, which is done in the name of securing the child's stability, simultaneously secures the stability of the newly-formed, or existing, nuclear family unit. And so we have individuation on the one hand - the articulation of the interest of the child in her own emotional stability - but a normative and normalising vision of childhood and child development on the other.

\section{Habituation}

The notion of the child's individual stability has also been specified in terms of the habituation of the child - in terms of the importance of the environment to which a child has become habituated. An example is to be found in Neulinger and Shuruk $v$ Switzerland (2010), which is one of the defining cases in European human rights law on the 'best interests' of the child in the context of international abduction proceedings.

The case concerned proceedings regarding the order for return of a little boy, Noam, who had been wrongfully removed (within the meaning of the Hague Convention on the Civil Aspects

\footnotetext{
${ }^{81}$ Lengthy proceedings, for example, in which a child is left in uncertainty as to where she will end up living have a notable potential effect on 'the child's mental equilibrium': Bronda v Italy (2001) 33 EHRR 4, para.62. And in Popov v France (2016) 63 EHRR 8, the ECtHR considered that the fact that the children were detained, along with their parents, in profoundly unsuitable conditions, effectively destabilised their worldview. The situation 'created anxiety, psychological disturbance and degradation of the parental image in the eyes of the children' (para.101). 82 eg Abrens v Germany ECtHR 22 March 2012; Kautzor v Germany ECtHR 22 March 2012; Krisztián Barnabás Tóth $v$ Hungary ECtHR 12 Feb 2013. See also, concerning the adoption of newborn babies and refusing - on the grounds of the stability of the adoptive family - the attempt of the biological mother to re-establish contact with the children, I.S. $v$ Germany ECtHR 5 June 2014.

83 On which see further S. Trotter, 'The ethos of replaceability in European human rights law', in N. Segal and J. Owen (eds.), On Replacement: Cultural, Social and Psychological Representations (forthcoming, London: Palgrave Macmillan, 2018).
} 
of International Child Abduction) by his mother from Israel to Switzerland. Noam and his mother argued that the order for Noam's return to Israel breached their Article 8 rights; and the Grand Chamber agreed. In particular, it considered that Noam's best interests would be better served by his staying in Switzerland than by his moving back to Israel, where there would be serious questions as to the capacity of his father to look after him. Noam was by now so well-settled in Switzerland that despite the fact that he was 'at an age where he still [had] a certain capacity for adaptation', uprooting him and returning him to Israel would likely carry 'serious consequences for him', which would outweigh any potential benefit of his return to Israel. ${ }^{84}$ The Court described this in terms of the 'habitual environment', from which it would be problematic to uproot Noam. ${ }^{85}$

This notion of the 'habitual environment' of a child has its source in the Hague Convention itself, which deals with the wrongful retention or removal of children and has, as one of its objectives, 'to establish procedures to ensure their prompt return to the State of their habitual residence... ${ }^{86}$ Here, however, 'habitual residence' alludes to the State in which the child was living prior to her wrongful removal or retention, ${ }^{87}$ whereas in Neulinger and Shuruk the Court used 'habitual environment' not in reference to the place (Tel Aviv) that Noam had been ordered to return to, but rather in reference to the environment that had since been established with his mother in Switzerland - the environment, in other words, that had been generated through the act that was 'wrongful' in the sense of the Hague Convention.

In constructing its notion of 'habitual' in this context, the ECtHR hints at what is, essentially, an assessment of the degree of social, cultural, and familial ties - an assessment which derives from its case law on expulsion measures, ${ }^{88}$ and is comparable to the principle of integration most favoured by the Court of Justice of the European Union in this context (a principle which, in turn, derives from its jurisprudence on free movement). ${ }^{89}$ Such an analysis, whether it is cast in terms of ties or integration, is looking not just at whether the child has settled, but at how she has settled, and her contribution to this settling; and this is what underpins the subtle distinction between the conceptualisation of habitual environment, which entails this latter fuller assessment

\footnotetext{
84 Neulinger and Shuruk v Switzerland (2012) 54 EHRR 31, para.147.

85 ibid, para. 147.

${ }^{86}$ Hague Convention of 25 October 1980 on the Civil Aspects of International Child Abduction, Preamble para.3.

87 ibid, Articles 3 and 4. 'Habitual residence' and 'habitual environment' are synonymous in the Hague Convention itself. See E. Pérez-Vera, 'Explanatory Report on the 1980 Hague Child Abduction Convention' (HCCH Publications, 1982), paras.11, 25. Available at: https://assets.hcch.net/upload/expl28.pdf (last accessed 30 May 2017). This is also how 'habitual environment' has mostly been used by the ECtHR (eg Maumousseau and Washington v France (2010) 51 EHRR 35, para.75; Carlson v Switzerland ECtHR 6 Nov 2008, para.80; K.J. v Poland ECtHR 1 March 2016, para.62).

$88 \mathrm{eg}$ Neulinger and Shuruk $v$ Switzerland (2012) 54 EHRR 31, para.146; Shaw v Hungary (2015) 61 EHRR 15, para.75.

89 Case 497/10 PPU, Barbara Mercredi v Richard Chaffe [2010] ECR I-14358, para.56.
} 
of ties or integration, and the second element of the best interests test, as to the development of the child in a 'sound environment'. Both, however, are ultimately about establishing conditions conducive to the child's development as this is envisaged in human rights law. The point being made is that disrupting the child's current stability could hinder her development.

And therein lies the real significance of this conception of 'habitual environment', from which we can derive a broader point about the developmental vision of childhood that is constructed in European human rights law. For this notion of habitual environment is not merely alluding to an environment with which one is familiar. Its articulation in terms of individual stability rather renders it more a matter of individual disposition, constitution ${ }^{90}$ and orientation. ${ }^{91}$ Its allusion is to an environment that is inhabited: the idea is of a habitual way of being. ${ }^{92}$ Gosden has suggested that such a form of life - which, on his account, would derive from our socialisation within a material setting - is to be distinguished from the realm of consciousness and meaning. ${ }^{93}$ Whilst '[1]ife is an intermingling of habitual and conscious elements', ${ }^{94}$ it is mostly habitual actions - unconscious actions - that link all our actions together and establish a 'referential structure... which carries the main burden of our lives, giving them shape and direction'. ${ }^{95}$ Habitual being is, in this way, deemed to enable continuity, and this is the case whether we are looking at social forms, as Gosden is, or at individual continuity through time.

The idea in human rights law that disrupting the stability - the habitual environment - of a child would disturb her development reflects this sense that the habitual aspect of our being is doing a lot of work. The existence of the habitual mode of being anchors the individual, and enables energy to be directed elsewhere. In the case of a child, this might immediately be, for example, to school life or peers (as in the case of Noam); later on, as parental authority withers, attention might be directed towards the role of the child as a member of society. ${ }^{96}$ The crucial idea is that habituation, as a process originating in childhood, is a precondition for the child's development; put more generally, the point is that it frees up a space for individual development. It grounds the process and pursuit of self-realisation by constructing and expressing a notion of

\footnotetext{
${ }^{90}$ On which see B. R. Andrews, 'Habit' (1903) The American Journal of Psychology 14(2), 121-149.

${ }^{91}$ See eg Mubilanzila Mayeka and Kaniki Mitunga v Belgium (2008) 46 EHRR 23, para.51 on the dependency of a five year old on its parents, such that 'when separated from its parents and left to its own devices, it will be totally disoriented'.

92 This connection between habit and mode of being originates in monastic life. See G. Agamben, The Highest Poverty: Monastic Rules and Form-of-Life (transl. A. Kotsko) (Stanford: Stanford University Press, 2013), 13-16.

${ }^{93}$ C. Gosden, Social Being and Time (Oxford: Blackwell Publishers, 1994), 11.

94 ibid, 35.

95 ibid, 16.

${ }^{96}$ See the later discussion of Osmanoğhu and Kocabas v Switzerland ECtHR 10 Jan 2017.
} 
our historical being: of 'the past's repetition in the present'; ${ }^{97}$ of how, psychically, we are 'historical persons..$^{98}$ Thus notions of the 'roots' of the individual, ${ }^{99}$ the 'degree' of her 'integration', ${ }^{100}$ and her 'original environment' ${ }^{101}$ come, later on, to find a place in human rights law. These are used as reference points that enable the individual to develop and be challenged outside the realm of her habitual environment whilst stabilising the otherwise fluid notion of this individual 'development'.

\section{The formation of the self}

The way in which European human rights law constructs childhood is, accordingly, in developmental terms. Childhood is cast as being a space and time in which a stable and secure environment - as underlying both processes of individuation and habituation - serves to cushion change and development. Underpinning this construction is the idea that childhood, as a period in development, is a critical time for the formation of conscience and the laying down of the self. Children are collectively cast as vulnerable ${ }^{102}$ and impressionable, ${ }^{103}$ as bearing a 'circumscribed autonomy...which gradually increases with their evolving maturity', ${ }^{104}$ and as needing to be 'moulded' in a particular way. ${ }^{105}$ The institution of the school - and in particular elementary education, which is 'of primordial importance for a child's development' ${ }^{106}$ - is deemed to serve a vital role in this regard. ${ }^{107}$ For the school has, as its objective, 'the development and moulding of the character and mental powers of its pupils' (to which end school discipline is deemed

\footnotetext{
${ }^{97}$ C. Carlisle, On Habit (Abingdon: Routledge, 2014), 25.

${ }^{98} \mathrm{~J}$. Mitchell, 'The Law of the Mother: Sibling Trauma and the Brotherhood of War' (2013) Canadian Journal of Psychoanalysis 21(1), 145-159, 146.

99 eg Aune v Norway (2012) 54 EHRR 32, para.78.

100 eg Üner v The Netherlands (2007) 45 EHRR 14, para.56 et seq.

$101 \mathrm{eg}$ the notion of the 'original criminal environment' with which an individual in detention is to have limited contact: Messina v Italy (No. 2) ECtHR 28 Sept 2000, para.66; Öcalan v Turkey (No. 2) ECtHR 18 March 2014, para.160; Enea v Italy (2010) 51 EHRR 3, para.126.

102 eg Handyside v UK (1979-80) 1 EHRR 737, para.52, in which the Court considered that the domestic judges were entitled to think that The Little Red Book would have 'pernicious effects' on the morals of children and adolescents, who were 'at a critical stage of their development', and 'could have interpreted' sections of the book 'as an encouragement to indulge in precocious activities harmful for them or even to commit certain criminal offences'. See also $V v U K$ (2000) 30 EHRR 121, para.87, in which the Court emphasised the sense of 'intimidation and inhibition' that a child defendant 'charged with a grave offence attracting high levels of media and public interest' would encounter in a criminal court, and, therefore, the need to 'conduct the hearing in such a way as to reduce as far as possible' such feelings, so as to ensure the effective participation of the child in the proceedings.

103 eg Dablab v Switzerland ECtHR 15 Feb 2001, in which the Court implied that the children, being aged between four and eight, were 'more easily influenced than older pupils', meaning that it was difficult to assess the impact on them of their teacher wearing the Islamic headscarf.

104 M. and M. $v$ Croatia ECtHR 3 Sept 2015, para.171.

105 Campbell and Cosans v UK (1982) 4 EHRR 293, para.33.

106 Timishev v Russia (2007) 44 EHRR 37, para.64.

${ }^{107}$ See also eg Catan and Others v Moldova and Russia (2013) 57 EHRR 4, para.144.
} 
fundamental), ${ }^{108}$ and it plays an integral role in the more general education and integration of children: 'the whole process whereby, in any society, adults endeavour to transmit their beliefs, culture and other values to the young. ${ }^{109}$ At primary level, this involves 'integration into and first experiences of society'; secondary education, meanwhile, plays 'an ever-increasing role in successful personal development and in the social and professional integration of the individuals concerned'. ${ }^{110}$

The emphasis here lies squarely on a notion of socialisation - on the inculcation, in 'the young', of particular modes of being that are considered to be socially valuable by the ECtHR, in the name of the Contracting States. This emerged markedly in Osmanoğlu and Kocabass v Switzerland (2017). The Applicants here were practising Muslims, who argued that the requirement that their daughters take part in mixed swimming lessons at school was contrary to their religious convictions. They complained, in particular, about the authorities' refusal to exempt the girls from the classes, alleging a violation of their right to freedom of religion under Article $9 .{ }^{111}$

The ECtHR accepted the argument of the Government that the interference with the Applicants' right to manifest their religion here - the refusal of the authorities to exempt the Applicants' daughters from compulsory mixed swimming lessons - pursued the legitimate aims of protecting the rights and freedoms of others and protecting public order. Specifically, the Court considered that the interference pursued the objectives of 'the integration of foreign children from different cultures and religions' and of 'protecting foreign pupils from social exclusion'. ${ }^{112}$ It elaborated these notions in its analysis of the necessity of the interference, in which it highlighted, in particular, the role of the school in the process of social integration - a role which took on an even greater significance when it came to 'children of foreign origin'. ${ }^{113}$ Compulsory education, it considered, plays an important role in a child's development; and the children's interest here in

108 Campbell and Cosans v UK (1982) 4 EHRR 293, para.33. See also Hasan and Eylem Zengin v Turkey (2008) 46 EHRR 44, para.55, in which the Court amended this statement slightly, noting the school's purpose of 'the development and moulding of the character and mental powers of its pupils as well as their personal independence'. This addition of 'personal independence' has not appeared in any of the cases concerning disciplinary penalties (eg Valsamis v Greece (1997) 24 EHRR 294, para.29; Efstratiou v Greece ECtHR 18 Dec 1996 , para.30; Dogru v France (2009) 49 EHRR 8, para.83; Ali v UK (2011) 53 EHRR 12, para.54).

109 Campbell and Cosans v UK (1982) 4 EHRR 293, para.33.

110 Ponomaryovi v Bulgaria (2014) 59 EHRR 20, paras.56-57. See also Horváth and Kiss v Hungary (2013) 57 EHRR 31, para.127.

111 The complaint was made under Article 9 ECHR because Switzerland has not ratified Protocol 1 of the ECHR, Article 2 of which protects the right of parents to ensure the education and teaching of their children in accordance with their religious and philosophical convictions.

112 Osmanoğlu and Kocabas v Switzerland ECtHR 10 Jan 2017, para.64 (my translation, as are all subsequent references to this case). (And on the objective of the integration of 'children of foreign origin', see also Harroudj $v$ France ECtHR 4 Oct 2012, para.51.)

113 ibid, para.96. 
receiving this full education, thereby enabling their 'successful social integration according to local mores and customs', consequently prevailed over 'the wish of parents to have their daughters exempted from mixed swimming classes' ${ }^{114}$ The domestic authorities had, consequently, not overstepped their margin of appreciation.

The emphasis here was very much on a vision of the development of the child - and not so much on her development as an individual, but rather on her development as a public 'member' of 'the community' into which she was being 'integrated' and a conception of which was, at the same time, being constructed. Thus whilst physical education, including swimming lessons, was deemed important for a child's health and development, the interest in this education was not limited to the fact of the children learning to swim and to engage in physical exercise. Rather, 'it resided especially in the fact of practising this activity in common with all the other pupils, with no exceptions being drawn based on the children's origin or their parents' religious or philosophical convictions. ${ }^{115}$ The value derived from the fact that the activity was being engaged in simultaneously, in common. It was irrelevant that swimming is a highly individualistic sport. What mattered was that the children were swimming simultaneously. They were learning together and practising this activity in common'; ${ }^{116}$ they were sharing time, and engaging, consequently, in what was conceived of as being the construction of a form of collective life. ${ }^{117}$

Hence also the emphasis placed by the Court on the longer term social lessons that the children would derive from this experience of being in common. In addressing the argument made by the Applicants as to the option of their daughters having private swimming lessons instead, it therefore not only reiterated its statement as to the value of the children swimming in common, but it also considered that granting an exemption from the lessons to children whose parents could pay for them to have private lessons would generate an inequality in relation to children whose parents could not afford this. In the same context, the Court recalled that the authorities had already offered to accommodate the Applicants, whose daughters could, for example, cover their bodies in the lessons by wearing burkinis. The implicit view was that it was important that children should learn the importance of being in common now, and that this should be impressed upon their sense of habitual being (a process cast in terms of their 'social integration'), because that would secure the continuity of this form of life in the long run. The children here were, in this

\footnotetext{
114 ibid, para. 97.

115 ibid, para.98.

116 ibid, para. 100.

117 See further S. Trotter, 'Living Together', 'Learning Together', and 'Swimming Together': Osmanoğlu and Kocabas v Switzerland (2017) and the Construction of Collective Life' (forthcoming) Human Rights Law Review.
} 
way, written into a conception of collective life at the same time as this conception was normatively inscribed upon their own mode of habitual being.

Childhood, within this vision, emerges as a critical social structure. It is presented as being an important time for the formation of the self and an important time for learning a particular set of rules (a process cast as 'social integration'). On the part of the child, a margin of error is assumed in the course of learning these rules. ${ }^{118}$ In one of the main strands of the expulsion case law, for example, concerning instances in which a State is seeking to expel an individual who has committed criminal offences in that State, the Court will consider the age of the individual at the time of the offences, ${ }^{119}$ and whether the offences were, for example, merely 'acts of juvenile delinquency'. ${ }^{120}$ Where the individual was a minor either at the time of the expulsion or at the time of the offences, the Court will have regard to the 'best interests' principle and, as part of this, to the obligation on the State to 'facilitate his or her reintegration'. ${ }^{121}$ The focus is on the potential for the individual to be 'reintegrated' into society and to change and develop ${ }^{122}$ - a line of thinking which underpins cases involving the sentencing and treatment of young offenders more generally, and in which the Court has emphasised the need to take account of 'developments in the young offender's personality and attitude as he or she grows older' - 'the changes that inevitably occur with maturation'. ${ }^{123}$ The years of childhood and young adulthood are thus cast as vitally formative of the self in European human rights law, both in terms of the processes of individuation and habituation that are laid down, and in terms of learning and socialisation.

\section{SELFHOOD}

The vision of childhood that emerges in European human rights law is also, then, a vision of selfhood. It is a vision in which childhood, and its emergent processes of individuation and habituation, in fact forms the core of the self. In this final part of the paper, I consider this process of self-formation in more detail. I suggest that childhood is presented here as supplying the framework of meaning through which life is subsequently structured. The idea that emerges from the case law is that understanding one's childhood is necessary in order for self-understanding to develop. This, in turn, is deemed important because it enables the formation of a narrative about

\footnotetext{
118 eg Emre v Switzerland (No 2) (2014) 59 EHRR 11, para.74, on how the criminal activities of the Applicant in question were 'errors of youth that he seems to have acknowledged'.

119 Maslov v Austria [2009] INLR 47, para.72.

120 ibid, para.81. See also eg Moustaquim v Belgium (1991) 13 EHRR 802, para.44. In terms of offences, cf eg Bouchelkia v France (1998) 25 EHRR 686, para.51; Kaya v Germany [2008] INLR 139, para.70; Onurv UK (2009) 49 EHRR 38, para.55; Joseph Grant v UK ECtHR 8 Jan 2009, para.40.

${ }^{121}$ Maslov v Austria [2009] INLR 47, para.83.

${ }_{122} A A v$ UK [2012] INLR 1, paras.60-69.

${ }^{123}$ Hussain v UK (1996) 22 EHRR 1, para.53.
} 
the self; and ultimately, what comes to light here is an account of the idea of 'the self' in European human rights law - an account of the 'narrative self.

\section{The meaning of childhood}

As we have already seen, childhood is presented in European human rights law as structuring the formation of the self. But this structuring function emerges more clearly still in cases in which the ECtHR is considering the significance and effect of childhood retrospectively. One of the most significant bodies of case law in this regard is that concerning the expulsion of 'second generation immigrants'. ${ }^{124}$ These cases concern individuals who were either born in or 'arrived in [a] host country at an early age', and on whom expulsion orders were subsequently served. ${ }^{125}$ The basic idea underpinning the case law here is that the earlier a young individual moved to a country, the more serious expulsion from that country is ${ }^{126}$ (though in cases involving serious offences, and reflecting what is essentially conceptualised as being a lack of commitment to the 'host' country, the age of the individual at arrival is less relevant ${ }^{127}$ ). In $C v$ Belgium (1996), for example, in which the Belgian authorities served a deportation order on Mr C., who had moved to Belgium from Morocco at the age of 11, the Court noted that the interference with his private life represented by this order 'was not so drastic as that which may result from the expulsion of applicants who were born in the host country or first went there as young children'. ${ }^{28}$ The order, which had been imposed on $\mathrm{Mr}$ C. following his conviction for a number of criminal offences, was considered to have struck a fair balance between the interests of the State in preventing crime and those of $\mathrm{Mr}$ C. in his private life. Thus the Court emphasised that although Mr C. had 'real links' with Belgium, in that he had lived there, was mostly educated there, and worked there, he had still 'preserved important links with Morocco'. ${ }^{129}$ It considered that he presumably knew the language, that it was in Morocco that his father had died, and that it was in Morocco also that 'he must have...established

\footnotetext{
124 eg Radovanovic v Austria (2005) 41 EHRR 6, paras.33-34.

125 ibid, para.34.

126 To be considered a 'second generation immigrant', it appears from the case law that the individual needs to have arrived in the country in question before the age of 10. Nevertheless, in a case concerning an Applicant who had indeed arrived at the age of 10 , the Court considered that although this meant that he was not 'a socalled "second-generation immigrant", it would still 'assess the necessity of the interference by applying criteria which are similar to those it usually applies in cases of second generation immigrants', given that 10 was a 'relatively young age': Keles v Germany (2007) 44 EHRR 12, para.56.

127 eg El-Boujaïdi v France (2000) 30 EHRR 223, para.40, on how, inter alia, the Applicant had potentially retained some linguistic links with Morocco, had 'never shown any desire to acquire French nationality', and had lived 'a life of crime' in France following an earlier conviction.

${ }^{128}$ C v Belgium (2001) 32 EHRR 2, para.34. (See also Dalia v France (2001) 33 EHRR 26, para.61, where the same statement was made in a case concerning an Applicant who had arrived in France at the age of 17 or 18.$)$

129 ibid, paras.33-34.
} 
his first social and school relationships', which later on included his relationship with a Moroccan woman. ${ }^{130}$

The question in these cases is, therefore, a question of ties. Where an individual was born in a country, or moved to that country at a young age, and lived the 'formative years' of her childhood there, the Court supposes that significant personal, social, and cultural ties will have been formed and that roots will have been laid down in that country. ${ }^{131}$ The idea is that the life of that individual will have been lived and understood through the lens of those ties. To use a term discussed earlier on in this paper, the individual will have become habituated to that country, and her life and relationships will make sense in its context. This notion of ties to place is accorded such a weight in European human rights law that it is often used in expulsion or residence refusal cases as a reason against expelling the parent of a child to another country, or refusing his or her residence, particularly if it would be very difficult for the child or the other parent (if the parents are still together) to move and live there too. ${ }^{132}$ It has also been used, in another line of case law, in support of upholding a separation of a child and parent on immigration grounds. An example is Abmut v The Netherlands (1996), which concerned the refusal of the authorities to grant a son (Souffiane) a residence permit to enable him to live in the Netherlands with his father (Salah Ahmut) - something which the Applicants argued had violated their Article 8 rights. The Court disagreed. It considered that Souffiane had spent most of his life in Morocco - 'his country', with which he had 'strong links with the linguistic and cultural environment'. ${ }^{133}$ The separation of Salah from his son had been a consequence of the decision of the former to settle in the Netherlands; moreover, the fact that he had sent his son to boarding school in Morocco meant that he had 'arranged for him to be cared for in Morocco'. ${ }^{134}$ The separation, the Court implied, was entirely of Salah's own making; and Article 8 does not 'guarantee a right to choose the most suitable place to develop family life'. ${ }^{135}$

\footnotetext{
130 ibid, para.34.

131 eg Osman v Denmark (2015) 61 EHRR 10, para.60. esp. para.48).

133 Ahmut v The Netherlands (1997) 24 EHRR 62, para.69.

134 ibid, para. 72.

135 ibid, para.71.
}

132 See eg Amrollabi v Denmark ECtHR 11 July 2002, para.41; Sezen v The Netherlands (2006) 43 EHRR 30, para.47; Rodrigues da Silva and Hoogkamer v The Netherlands (2007) 44 EHRR 34, para.44; Zakayev and Safanova v Russia ECtHR 11 Feb 2010, paras.45-48. If the child is of an 'adaptable age', however, it may well be different: see eg Ünerv The Netherlands (2007) 45 EHRR 14, para.64; Arvelo Aponte v The Netherlands ECtHR 3 Nov 2011, para.60. The same basic principle (as to expulsion being potentially obstructed by the difficulties that it would entail for family members) applies in relation to the spouse of an individual (see Boultif v Switzerland (2001) 33 EHRR 50, 
The framing of this case, in terms of a balancing between the interests of the Applicants and those of the State in 'controlling immigration', ${ }^{136}$ and in terms of the capacity of Salah to move to Morocco, was also a framing which attached great weight to Souffiane's ties to Morocco. Thus, and in the face of what Judge Valticos, in his Dissenting Opinion conceived of as being the parental right of Salah 'to have his son by him, to guide him, to supervise his education and training and to help him choose and begin a career and as it were to prepare the projection of his own life into the future by contributing to a happy and productive life for his child' (a construction of the sort considered earlier: the child as extension of the parent), ${ }^{137}$ the majority placed greater emphasis on the way in which Souffiane had lived most of his life in Morocco. The idea was that these ties to a place, formed early on in his life, structured his life.

It is in this way that childhood, and the ties of childhood, carries a vital meaning in European human rights law. Childhood is constructed as supplying a framework of 'intelligibility' - 'a framework of significance' through which life makes sense and into which everything fits. ${ }^{138}$ It shapes the direction that the life of an individual goes on to take; and specific childhood experiences are cast in law as structuring subsequent life and events, and as serving as a sort of reference point against which these later events or modes of being are explained. These experiences are always, of course, also interpreted by the ECtHR against the backdrop of its normative account of child development, which we looked at earlier on, and in which the role of a stable childhood environment emerged as vital. And so, to take an example, in cases of childhood trauma European human rights law goes about constructing an account of the child's experience through the lens of adjustment, with the question being of what a child could, in theory, adjust to. ${ }^{139}$ In some cases, the view is that adjustment is not a likely option. In $Z$ and Others $v U K$ (2001), for instance, in which it was found that the local authority had failed to protect the Applicant children from the severe abuse and neglect that they had suffered at the hands of their parents, the ECtHR considered, in its assessment of damages, that the children would in all probability, suffer from the effects of their experiences for the rest of their lives', even though '[their] capacity to cope with this past trauma' would vary. ${ }^{140}$ Such a mode of analysis, focused on adjustment, entails the construction of a vision of what is likely to be traumatic for a child - a vision of 'child-specific reactions to trauma'. ${ }^{141}$ Whilst this account originates in the more general vision of child development

\footnotetext{
136 ibid, para.73.

137 ibid, Dissenting Opinion of Judge Valticos.

138 On this notion of intelligibility, see J. Lear, Radical Hope: Ethics in the Face of Cultural Devastation (Cambridge MA: Harvard University Press, 2006), 41.

139 eg Tonchev v Bulgaria ECtHR 19 Nov 2009, para.39. See also Gnahoré v France (2002) 34 EHRR 38, para.60.

$140 Z$ and Others $v$ UK (2002) 34 EHRR 3, para.123.

141 M.G.C. v Romania ECtHR 15 March 2016, para.65.
} 
constructed in European human rights law, it also becomes a predictive, normative account of how a life will be subsequently lived. The idea underpinning the Court's point in $Z$ and Others, for example, was that the traumatic experiences of the children here would structure, to some degree, their future lives and experiences. For childhood, after all, is presented as supplying the framework of meaning through which life is subsequently lived.

\section{Understanding childhood}

The vision of childhood set out in European human rights law is, therefore, one which acquires a quality of timelessness. 'Childhood' is constructed as a framework of meaning through which life is lived and makes sense - as an overarching and timeless 'primordial structure', which shapes and informs the remainder of an individual's life. ${ }^{142}$ The idea is that things in a life - events, actions, experiences - occur against the backdrop of childhood and can be explained with reference to it; and it is consequently unsurprising that, in the jurisprudence, much weight is placed on the importance of understanding one's childhood.

This notion was first expressed by the ECtHR in Gaskin v UK (1989). Mr Gaskin had spent most of his childhood in care, following the death of his mother when he was a young baby. He alleged that he had been ill-treated in care, and upon reaching the age of 18 in 1977, he began trying to obtain access to confidential information about his care, held by the authorities, on the ground that learning about his past would help him to overcome his present difficulties. The authorities refused to grant him access to all his case records, and Mr Gaskin complained before the ECtHR that this breached his right to respect for his private and family life under Article 8.

The Court considered, firstly, that the case records contained in the file about Mr Gaskin related sufficiently to his private and family life such that the lack of access to the file fell within the ambit of Article 8. It agreed with the then-Commission, which had already considered the case, that the file 'no doubt contained information concerning highly personal aspects of the applicant's childhood, development and history and thus could constitute his principal source of information about his past and formative years'. ${ }^{143}$ The question was whether the UK had breached a positive obligation in its handling of Mr Gaskin's requests for access to his file.

The ECtHR held that it had. On the one hand, it considered, there was the 'vital interest' of those in the position of $\mathrm{Mr}$ Gaskin in receiving the information necessary to know and to

\footnotetext{
142 On this notion of timelessness see J. Lear, 'Wisdom Won from Illness', in Wisdom Won from Illness: Essays in Philosophy and Psychoanalysis (Cambridge MA: Harvard University Press, 2017), 11-29, 19 et seq.

143 Gaskin v UK (1990) 12 EHRR 36, para.36.
} 
understand their childhood and early development'. ${ }^{144}$ On the other hand, there was the confidentiality of public records, which was important 'for receiving objective and reliable information', and for ensuring the protection of third parties. ${ }^{145}$ To be compatible with Article 8 , the British system, which required the consent of the contributor before granting access to the records supplied by that contributor, needed to secure the protection of the individual's interest in the event that the contributor 'either is not available or improperly refuses consent'. ${ }^{146}$ 'This was to be enabled by an independent authority that had the final decision on access. The absence of such a procedure in this case meant that there had been a failure to secure respect for Mr Gaskin's private and family life - a failure to protect his interest in understanding and knowing his childhood.

The sense emerging from this case and from subsequent case law concerning the same issue of access to social service records about one's childhood is that we need to be able to understand our childhood in order to understand our self, our individual identity. ${ }^{147}$ This connection between childhood and selfhood was further drawn out in Haas $v$ The Netherlands (2004). At issue in that case was Mr Haas's complaint that as a legally unrecognised 'illegitimate' child, he was unable to inherit from his purportedly biological father, P. - something which, he argued, violated his rights under Articles 14 and 8. He alleged that though P. and his mother had not lived together, and P. had not legally recognised him as his son, P. had contributed towards his maintenance and had bought him birthday presents, and he, in turn, as a child had called P. 'Daddy'. The Court, for its part, however, considered that Article 8 had no applicability in this case, meaning that Article 14 could not be relied on. It considered that the 'sporadic contacts' between P. and the Applicant, and the 'alleged fatherly acts on P.'s part towards him', did not constitute 'family life' within the meaning of the Convention. ${ }^{148}$ Moreover, Mr Haas was only seeking to be recognised as P.'s son in order to have a claim to inheritance against P.'s estate; his

\footnotetext{
144 ibid, para.49.

145 ibid, para.49.

146 ibid, para.49.

${ }^{147}$ See esp. MG v UK (2003) 36 EHRR 3, in which the Applicant alleged that there had been inadequate disclosure of his social service records by the local authority, in breach of his Article 8 rights. As in Gaskin v UK (1990) 12 EHRR 36, the Court here considered that the records '[contained] the principal source of information regarding periods of the applicant's formative years' (para.28), and also noted that one of the Applicant's main reasons for seeking access to his records was 'his sincere belief that he had been physically abused when he was a child by his father and his need to obtain as much information as possible about that period in order to come to terms with the emotional and psychological impact of any such abuse and to understand his own subsequent and related behaviour' (para.29). cf the Court's distinction, at para.29, between the facts of this case and those of Martin v UK (1996) 21 EHRR CD112, in which a similar request for records was made concerning mental health treatment that the Applicant had intermittently received when he was approximately 19 years old, and in regard to which, the then-Commission considered, 'the question of reconstituting information in relation to his childhood from the relevant records does not arise'.

148 Haas $v$ The Netherlands (2004) 39 EHRR 41, para.42.
} 
intention had never been 'to have his claim to be P.'s son accepted in order to provide him with the emotional security of knowing that he is part of a family, even less so to enable him to create ties with P.'s surviving family circle or to resolve any doubts he may have about his own personal identity' ${ }^{149}$ The latter claims, the Court implied, were worthier, and would have merited greater attention; for whereas it is not possible to derive from Article 8 'a right to be recognised as the heir of a deceased person for inheritance purposes', ${ }^{150}$ rights pertaining to one's self-understanding, and to one's personal identity - and, therefore, to knowledge and understanding of one's childhood and background, for this purpose - do form part of Article $8 .{ }^{151}$

\section{The narrative self}

The idea that one's self-understanding is dependent on an understanding of one's childhood is a development of the point, earlier discussed, that European human rights law locates the origins of the self in another. An individual's understanding of her childhood is presented in law as enabling her to embark on the process of crafting a narrative about her self; and this narrativity, in turn, is engaged in human rights law as the means through which the continuity of the self across time is established. Thus whilst the act of living itself is not an act of narration, the act of narration, as an act - an attribution - of meaning, ${ }^{152}$ emerges in law as a means of organising and coming to terms with life and its unpredictability. It is a form of 'self-understanding' generated through 'narrative reflection'. ${ }^{153}$ The narrative form is used as a means through which to create a story about the self; and, to this end, it serves to cover over breaks and breaches in the temporal experience of an individual ${ }^{154}$ - breaks and breaches which would otherwise disrupt the very notion of the selfcontinuity of this individual. The production of narrative becomes, in this way, an act of defence - a defence of the individual, and her self-understanding, against these breaks and disruptions.

One of the ways in which the narrative form works in this way is by containing anxiety and situating it within a greater narrative. This can be seen in a line of cases involving the allegations of anguished relatives that they themselves have been victims of inhuman and degrading treatment

\footnotetext{
149 ibid, para.42.

150 ibid, para.43.

151 See eg Jäggi v Switzerland (2008) 47 EHRR 30, para.26, in which the Court distinguished a claim seeking to establish biological ties between an Applicant and his purported biological father and a claim pertaining to inheritance rights.

152 On which see J. Bruner, Acts of Meaning (Cambridge MA: Harvard University Press, 1990); D. P. Spence, Narrative Truth and Historical Truth: Meaning and Interpretation in Psychoanalysis (New York and London: W. W. Norton \& Company, 1982); J. Bruner, Making Stories: Law, Literature, Life (Cambridge MA: Harvard University Press, 2002).

153 M. Freeman, Hindsight: The Promise and Peril of Looking Backward (Oxford: Oxford University Press, 2010$), 4$.

154 An example of this is the jurisprudence on traumatic experiences in adulthood. On this function of narrative, see J. Lear, Happiness, Death, and the Remainder of Life (Cambridge MA: Harvard University Press, 2000), 125-126.
} 
on account of the indifference and incompetence displayed by the authorities in the face of the disappearance of their family members. ${ }^{155}$ The essence of the concern of European human rights law in its response in these instances pertains to the continuing void of anxiety into which the relatives have been plunged as to the fate of their loved ones. ${ }^{156}$ Once they are out of this void once the death of their relatives, for example, has been confirmed as a certainty - it is different. ${ }^{157}$ This is because the anxiety at the core of these cases is, as it is conceived of in law, a matter of anxiety about fate - a matter of not knowing something that can be settled by an account of events. The narrative form appears, therefore, to contain anxiety. It puts it into a narrative framework and imposes some order on it. ${ }^{158}$

The use of the narrative form to 'cover over the countless breaks in which life opens up or breaks apart ${ }^{159}$ - to contain disruptions and anxieties - presupposes, of course, that there is some certainty about the narrative that is being offered up. But this is where two problems arise that human rights law has to address. The first is that a choice must always be made, not only between multiple and conflicting narratives, ${ }^{160}$ but also as to from where to begin the narrative something seemingly settled as 'childhood' in European human rights law. The second problem which, in fact, also troubles the first - is that narrative itself is an unstable form. In the early 1980s, this was raised by Spence in his critique of the Freudian narrative tradition in psychoanalysis, whereby, he claimed, psychoanalysts had been led to become 'searchers after meaning', looking for 'coherence and continuity'. ${ }^{161} \mathrm{He}$ argued that there had been a failure to distinguish 'narrative truth' (with its presentation of a coherent account) and 'historical truth' (what actually happened). Thus, Spence suggested, in the dominant assumption that the freely-associating patient had 'privileged access to the past', and that the story being heard by the analyst was the same one as

155 eg Kurt v Turkey (1999) 27 EHRR 373; cf Cakici v Turkey (2001) 31 EHRR 5; Ciçek v Turkey (2003) 37 EHRR 20; Bazorkina v Russia (2008) 46 EHRR 15; Osmanoğlu v Turkey (2011) 53 EHRR 17; Betayev and Betayeva v Russia ECtHR 29 May 2008; Ibragimov and Others v Russia ECtHR 29 May 2008; Gekhayeva and Others v Russia ECtHR 29 May 2008; Khadzhialiyev and Others v Russia ECtHR 6 Nov 2008; Varnava and Others v Turkey ECtHR 18 Sept 2009; Janowiec and Others $v$ Russia (2014) 58 EHRR 30.

${ }_{156}$ See eg Varnava and Others v Turkey ECtHR 18 Sept 2009, paras.200-202; Zorica Jovanović v Serbia (2015) 61 EHRR 3, paras.47-48.

157 eg Janowiec and Others $v$ Russia (2014) 58 EHRR 30.

158 On narrative as a way to cope with unpredictability and uncertainty, see Bruner (2002), n 152 above, 89.

${ }^{159}$ Lear (2000), n 154 above, 125.

${ }^{160}$ An example of this in the jurisprudence is that of the two narratives of 'biological truth' and (social) 'stability' that are apparent in the context of paternity challenges (see cases at $\mathrm{n} 82$ above). A comparable distinction has haunted the jurisprudence on gender identity, which up until the start of the present century involved a split between individual constitution in law (which adhered to a static biological model) and individual constitution in fact (which did not). (On the 'biological' narrative, see eg Rees v UK (1987) 9 EHRR 56; Cossey v UK (1991) 13 EHRR 622; X, Y, and Z v UK (1997) 24 EHRR 143; Sheffield and Horsham v UK (1999) 27 EHRR 163. The shift away from this occurred only with Goodwin v UK (2002) 35 EHRR 18.)

${ }^{161}$ Spence (1982), n 152 above, 22-23. Repeating similar concerns, see Lear (2000), n 154 above, 125-126. 
that which the analysand was telling, there lay the tempting conclusion that what was being heard was a piece of history, an account of the 'way things were'. ${ }^{162}$ Spence argued that this confused narrative and historical truth, and represented a failure to see that 'the past is continuously being reconstructed in the analytic process'. ${ }^{163}$

If the acts of giving or hearing an account of experience intrinsically involve a working on its form, then not only is there, as we already know, a construction of a narrative - the conferral of coherence and a semblance of continuity on an account - but, in the case of European human rights law, there is a reconstruction of 'childhood' (as the beginning of narrative) itself. And so whilst an individual's understanding of her childhood may well be presented in law as enabling her to embark on the process of forming a narrative about her self, in the very course of that process of narration, her childhood itself will be reimagined - a reimagination of a space and time of experience which affords the possibility of its idealisation. ${ }^{164}$ Her own self will also be reimagined too, of course, since a 'narrative self, such as that which is envisaged in European human rights law, entails its continual reconstruction.

The implications that flow from this vision of the self are significant. For whilst, on the one hand, childhood and selfhood are, as we know, constructed as mutually dependent in European human rights law, it follows from the notion of the narrative self that they also, on the other hand, necessarily undermine each other. Childhood, we know, is constructed in human rights law as being the time and space in which crucial processes of self-formation (individuation and habituation) take hold; and an understanding of childhood is cast as being necessary for an understanding of the self. At the same time, however, that very understanding of childhood, which is constructed as enabling the formation of narrative, is itself paradoxically undermined by the exercise of that possibility. This is because the act of narration entails the reimagination of the original understanding of childhood - as the source of narrative - itself. Thus 'selfhood', in European human rights law, undermines its own origins; and what remains is a vision of the narrative self, the condition of the possibility of which consists in its continual reconstruction.

\section{CONCLUSION}

The work performed by the category of 'the child' in European human rights law is not only, therefore, the work of conceptualising 'the child', but also the work of conceptualising 'the self.

\footnotetext{
162 Spence (1982), n 152 above, 27.

163 ibid, p93.

164 This offers one potential explanation as to the idealisation of childhood in some strands of critical theory, on which see R. Neustadter, 'An End to "Childhood Amnesia": The Utopian Ideal of Childhood in Critical Theory' (1992) Mid-American Review of Sociology 16(2), 71-80.
} 
From the outset, the two notions are intertwined. In the first instance, 'the child' comes into European human rights law in the context of 'the parent', being firstly, and individually, the object of an individual's imagination of his or her self as 'parent', and being secondly located within a parental relationship and constructed as an extension of the parent(s). Such is the weight that is accorded to the 'other' in the process of constructing 'the child' that the very subjectivity of the child is conceived of as being bound up in another - a vision which underlies the way in which the right to knowledge of origins is conceptualised in European human rights law as involving the location of personal identity in another. The origins of 'the child' in European human rights law are, therefore, as much about 'the child' as they are about the origins of 'the self.

The way in which childhood is subsequently conceptualised involves a development of this original account. Childhood is conceived of in developmental terms, and as involving the instigation of two processes which are critical for the formation of the self. These are individuation and habituation. The process of individuation is about the delineation of the specific child, and the articulation of her individual interests, as distinct from those of her parents. The process of habituation is about the engraining of actions and elements of being as habits, such that they become unconscious features of an individual's character. The way in which childhood, conceived of as involving the origins of these processes, is cast as formative of the self involves a vision of it as supplying a timeless framework of meaning through which life is subsequently structured and interpreted. The underlying idea appears to be that an account of childhood enables selfunderstanding, because it enables the individual to embark on a process of crafting a narrative about her self. What comes to light through this vision of childhood, then, is European human rights law's account of 'the narrative self'.

And so within the vision of European human rights law, 'the child' emerges as a fundamental category. Not only is close study of this category valuable insofar as it enables a critical reflection on the sorts of normative and normalising qualities that underpin legally constructed categories, but it also enables analysis of the vision of the human condition that underpins European human rights law more generally and runs throughout its jurisprudence. The category of 'the child' in European human rights law leads us to the category of 'the self'; and law's account of childhood, which is cast as involving processes critical to the formation of the self, thereby becomes an account of selfhood. Childhood and selfhood are, in this way, mutually dependent. And yet, as I have argued in this piece, this mutual dependency consists in the mutuality of the undermining of each by the other, such that whilst an understanding of childhood is deemed vital in enabling the formation of a narrative about the self, the very process of this narration entails a reimagination of what was once this original understanding. If this demands a vision of the 
narrative self as a self that is continually reconstructed, herein also lies its transformative potential. For if a narrative self entails self-construction and self-reconstruction, then this appears to offer an ultimate way out of the confines of legally constructed categories - a way which originates in law, in the category of 'the child', but also offers the possibility for transcending this very category. 